\title{
Knowledge, Attitude and Practice of Pregnant Mothers towards Preventions of Iron Deficiency Anemia in Ethiopia: Institutional Based Cross Sectional Study
}

\author{
Abdu Oumer ${ }^{1 *}$, Arif Hussein ${ }^{2}$ \\ ${ }^{1}$ Department of Public Health, College of Health Science, Ethiopia; ${ }^{2}$ Department of Nursing, College of Health Science, Ethiopia
}

\begin{abstract}
Background: Globally 56 million (41.8\%) of pregnant women had anemia. Low maternal risk perception, poor dietary practice and low adherence to iron tablets among pregnant women are major contributors for high burden of anaemia. Thus the level of maternal awareness and attitude towards dietary and other prevention practices of anaemia are not well established in the study area.

Objectives: To assess the knowledge, attitude and practice of pregnant mother towards the prevention of iron deficiency anaemia in Ethiopia, 2018.

Methods: This is institutional based cross sectionals study conducted on randomly selected, 128 pregnant mothers attending antenatal care service in Harar town. Data was collected by health professionals using pre tested questionnaire containing socio demographic, knowledge, attitude and practice related questions. Good and poor knowledge was scored by coding the correct answers as one. Attitude questions were organized in five likert scale from strongly disagree to strongly agree using positive statements. Similarly practices were assessed in yes/no (appropriate practices were scored as yes or no otherwise). The three indicators were transformed in to categories using the mea score as cut off point. Data was analysed using SPSS version 20 using frequency, tables, graphs and means. Pearson correlation with $\mathrm{r}$ was used to assess the relationship between knowledge, attitude and practice. ANOVA was used to compare the mean practice by different factors.

Results: Total of 128 mothers were interviewed with mean age of 26.3 (SD=5.8 y). Overall, $61 \%$ (95\% CI: $52.6 \%$ to $69.5 \%$ ) of pregnant women had a good knowledge on prevention methods of IDA. More than half, $52.3 \%$ (95\% CI: 43.7\% to $61.0 \%$ ) had favorable attitude towards prevention of IDA. While majority of pregnant women, 58.6\% (95\% CI: 50.1\% to $67.1 \%$ ) had poor adherence to prevention practice of IDA.

Conclusion and recommendations: Knowledge, attitude and practice of pregnant women on preventions of IDA are not satisfactory. Thus poor practice towards prevention of IDA are the main contributing factor for high burden of anemia. Generally there should be focused, simple, easy to understand and customer friendly counseling service at ANC facilities.
\end{abstract}

Keywords: Iron deficiency anaemia (IDA); Prevention; Knowledge; Attitude; Practices

Abbreviations: ANC: Ante Natal Care; AOR: Adjusted Odds Ratio; CI: Confidence Interval; IDA: Iron Deficiency Anaemia; r: Correlation Coefficient; WHO: World health Organization.

\section{INTRODUCTION}

A balanced amount of nutrients in food is needed for all human being for proper body system functions. This indicates that Nutrition is a fundamental pillar for the human being, for the health and development of entire life [1-3]. Now a day for both developed and developing country malnutrition is the great problem globally, more specifically under-nutrition and micronutrient deficiencies are widespread problems in developing countries [4,5].

The nutritional requirement of individual greatly varies with each physiological change in each stages of life. Among this micronutrient deficiencies during the first 1000 days of life are associated with poor maternal health and neonatal outcomes like morbidity, mortality, cognitive loss and congenital deformities. Low birth weight from anemia and other causes accounts more than 800,000 deaths each year in neonatal death [6,7].

Pregnancy is a period of significant increase in iron requirement; the demand for iron is higher due to physiological changes in maternal red blood cell mass and increasing needs of development, placenta and fetus [1]. Iron is needed in significant amount to support maternal and fetal growth. Despite increased iron requirements, pregnancy is also a period of increased risk for

Correspondence to: Abdu Oumer, Department of Public Health, College of Health Science, Ethiopia, E-mail: phnabu2@gmail.com

Received: January 04, 2019; Accepted: January 28, 2019; Published: February 04, 2019

Citation: Oumer A (2019) Knowledge, Attitude and Practice of Pregnant Mothers towards Preventions of Iron Deficiency Anemia in Ethiopia: Institutional Based Cross Sectional Study. Health Care Current Reviews 7: 238. doi: 10.35248/2375-4273.19.07.238.

Copyright: (c) 2019 Oumer A. This is an open-access article distributed under the terms of the Creative Commons Attribution License, which permits unrestricted use, distribution, and reproduction in any medium, provided the original author and source are credited. 
anemia which is higher than in non-pregnant state $[2,8]$. The presence of Iron deficiency anemia (IDA) has been associated with decreased cognitive index, low birth weight and increased neonatal mortality [9].

According to World Health organization (WHO) definition of Anemia is "A condition in which the number of red blood cells (RBCs) or their oxygen-carrying capacity is inadequate to meet physiologic demands in the body”. Anemia in pregnancy is identified by the WHO as hemoglobin level less than $11 \mathrm{~g} / \mathrm{dl}$ [10,11].

Globally, the most common cause of anemia is iron deficiency, which is responsible for about half of anemia cases in pregnancy, it is estimated in developed countries, about $38 \%$ of pregnant women had iron depletion [12]. Globally, anemia affects 1.62 billion people (95\%; CI:1.50-1.74 billion) with prevalence of $24.8 \%$, out of whom an estimated, 56 million (41.8\%) of pregnant women had anemia, where iron deficiency is thought to be the most common cause of anemia which account for $75 \%-95 \%$ of cases $[1,10]$. Globally an estimated, 56 million (41.8\%) of pregnant women had anemia [12,13]. But majority of pregnant mothers lack correct perception [14]. As of the WHO recommendations to achieve the sustainable development goals, as one of the strategic objective awareness raising has got a great deal especially with invisible forms of malnutrition like anemia. In 2018, an estimated 264 million women of reproductive age are affected by iron-deficiency anaemia. With the current global effort to eliminate the current global malnutrition by 2025, IDA is one of the great Nutritional concerns worldwide [4].

Worldwide estimates of IDA showed the prevalence of anemia in Africa, reaches up to $52 \%$. The estimates range from $18 \%$ in developed Countries and to $56 \%$ in developing countries. Global prevalence of anemia for pregnant women was $38.2 \%$ and for all women of reproductive age was $29.4 \%$ with an estimated 32.4 million pregnant women were anemic [15].

Even though burden of anaemia among pregnant mothers has declined from $43 \%$ to $38 \%$ over the past decades it still showed that the world Health Assembly (WHA) target of 50\% (as compared to $12 \%)$, reduction of anaemia by 2025 is far and countries need to focus on achieving this target in near future [1].

The prevalence of anaemia in Ethiopian among women of 15-49 age group was $17 \%$ and $22 \%$ among pregnant, $27.9 \%$ in southeast Ethiopia and 39.4\% in southern Ethiopia [16-18]. Similarly higher prevalence of anemia is reported in different parts of the country [19-21]. Lack of awareness, poor dietary practice and inappropriate dietary counseling of pregnant mothers are major contributors to high burden of anemia. It is also evident that only $72 \%$ of mothers are aware of anemia. Anaemia was found to be severe public health problem in Ethiopia that is greater than $40 \%$ of pregnant women were anaemic [16].

Despite anemia having been identified as a global public health problem for several years, no rapid progress has been observed, and the prevalence of the disease is still high globally [1]. Strategies for reduction and control of anaemia among women are one of the public health concerns worldwide [2].

Therefore, the aim of the study was to assess level of knowledge, attitude and practice of pregnant mothers attending Ante natal care (ANC) on prevention of Iron deficiency anaemia. This study will give baseline evidence on the level of maternal awareness and intention to practice good dietary practices among pregnant. Thus it will be valuable input for targeted behavioral interventions.

\section{METHODS}

\section{Study design and area}

Institutional based cross sectional study was conducted in Harari region, Eastern Ethiopia total population of 250,903 in 2018. Out of this, $139,200(60 \%)$ resides in urban while 116,928 are males with estimated 64,939 were in reproductive age groups. The region is composed of 9 words with 19 urban and 17 rural kebeles [22].

According to Harari Health Bureau reported in 2015 Harari region health coverage was estimated to be $100 \%$. There are three public hospitals, two private hospital, eight health centers, 20 health post and about 18 private clinics in the region. The Total number of pregnant women in this region was 7169.

\section{Sample size determination}

The required sample size was determined by using single population proportion formula using the prevalence estimate of good knowledge (p1), attitude ( $\mathrm{p} 2)$ and practice (p3) from previous studies. Using knowledge towards nutritional anemia among pregnant women (P1) estimate the sample size is calculated as follows:

$n=\frac{(Z \alpha / 2)^{2} p(1-p)}{d^{2}}$

Where,

$Z=$ critical value for normal distribution at $95 \%$ confidence level which equals to 1.96 ( $z$ value at $[=0.05$, two tailed).

$\mathrm{P}=$ Proportion $69 \%$ had good knowledge about prevention of IDA [23].

$\mathrm{n}=$ sample size

$\mathrm{d}=$ margin of error $=5 \%$ in case of our study $=0.05$

For $\mathrm{p} 1$,

$n=\frac{(Z \alpha / 2)^{2} p(1-p)}{d^{2}}=\frac{(1.96)^{2} * 0.69 *(1-0.69)}{(0.05)^{2}}=329$

Using attitude towards nutritional anaemia among pregnant women (P2) the sample size was estimated as follows.

$n=\frac{\left(Z^{\alpha} / 2\right)^{2} p(1-p)}{d^{2}}$

Using above formula, taking proportion of the respondent who had positive attitude towards using iron supplement to prevent anaemia as $82.2 \%$, the sample size was 73 [24]. For the third objective taking $59.5 \%$ ANC attending women were following good practices to prevent anaemia in pregnancy, the sample size was 372 [23].

For $\mathrm{p} 3$,

$$
n=\frac{(Z \alpha / 2)^{2} p(1-p)}{d^{2}}=\frac{(1.96)^{2} * 0.59 *(1-0.59)}{(0.05)^{2}}=372
$$

Using above formula, taking proportion of the respondent who had positive attitude towards using iron supplement to prevent anaemia as $82.2 \%$, the sample size was 73 [24]. For the third objective taking 
59.5\% ANC attending women were following good practices to prevent anaemia in pregnancy, the sample size was 372 [23].

$n=\frac{n}{1+\frac{n}{n}}$

$n=\frac{409}{1+\frac{409}{186}}$

So the final sample size calculated was 128 .

\section{SAMPLING TECHNIQUE/ PROCEDURES}

The total sample size was proportionally allocated to Hiwot Fana specialized University Hospital and Jugol Hospital. Jugol Hospital with average monthly flow of pregnant mothers $(n=70)$ and Hiwot Fana specialized university Hospital $(n=116)$. Thus 48 and 80 clients were selected using simple random sampling from Jugol Hospital and Hiwot Fana specialized university Hospital respectively.

\section{DATA COLLECTION METHODS}

Data was collected using structured questionnaire, containing sociodemographic, knowledge related, attitude and practice related questions on prevention of IDA among pregnant women. The tool was prepared by English version and translated to local language (Oromiffa and Amharic) by trained nurse professionals. Sets of questions were adapted from previous studies and literatures were used to assess knowledge, attitude and practice towards IDA. One day supportive training, close supervision and daily check-up of the collected data were done to improve the quality of data. The collected data was entered in to statistical package for social science (SPSS version 20) and checked for consistency and outliers before analysis.

\section{METHODS OF DATA ANALYSIS}

Cleaned data was entered in to SPSS version 20. The data was presented using frequency, percentage, table and graph. In addition the knowledge, attitude and practice score was done by using compute command. The knowledge, attitude and practice score was categorized to (good versus poor knowledge and practice) (Positive versus negative attitude) using mean score as cut off point.

\section{RESULT}

\section{Socio-demographic characteristics of the participants}

Out of the total 128 pregnant women, majority 39 (30.5\%) found under age category of $23-27$ y and 107 (83.6\%) were married. On their education status majority 50 (39.1\%) were diploma and above, with 59 (46.1\%) working in governmental institution. Regarding family size, 78 (60.9\%) has two family members, with majority, 106 $(82.8 \%)$ of them live in urban (Table 1$)$.

\section{MATERNAL CHARACTERISTICS}

Regarding age at first marriage, about $65(50.8 \%)$ of pregnant women married at age between $16-20 y$. About, 65 (50.8\%) gave their first birth at age of $18-22$ y. Majority, 103 (80.5\%) of the respondents did not suffer from health related problem during the first birth. Almost half they were their initial visit to the hospital (Table 2).

\section{KNOWLEDGE ON IRON DEFICIENCY ANAEMIA}

Out of the total, $113(88.3 \%)$ of pregnant mothers have ever heard about IDA, in which health professionals were main source of information. About 40 (31.3\%) of pregnant mothers correctly
Table 1: Socio-demographic characteristics of pregnant women attending ante-natal care at Public Hospitals of Harar town, Eastern Ethiopia, 2018.

\begin{tabular}{|c|c|c|c|}
\hline Variables & & Frequency & Percentage \\
\hline \multirow{6}{*}{$\begin{array}{l}\text { Age categories in } \\
\text { years }\end{array}$} & $18-22$ & 38 & 29.7 \\
\hline & $23-27$ & 39 & 30.5 \\
\hline & $28-32$ & 33 & 25.7 \\
\hline & $33-37$ & 13 & 10.2 \\
\hline & $38-42$ & 2 & 1.6 \\
\hline & $43-47$ & 3 & 2.3 \\
\hline \multirow{4}{*}{ Marital status } & Single & 3 & 2.3 \\
\hline & Married & 107 & 83.6 \\
\hline & Divorced & 15 & 11.7 \\
\hline & Widowed & 3 & 2.3 \\
\hline \multirow{3}{*}{$\begin{array}{c}\text { Educational } \\
\text { Status }\end{array}$} & Primary school & 28 & 21.9 \\
\hline & Secondary school & 50 & 39.1 \\
\hline & Diploma and above & 50 & 39.1 \\
\hline \multirow{4}{*}{$\begin{array}{l}\text { Occupational } \\
\text { status }\end{array}$} & Farmer & 13 & 10.2 \\
\hline & Governmental & 59 & 46.1 \\
\hline & Private & 34 & 26.6 \\
\hline & House wife & 22 & 17.2 \\
\hline \multirow{3}{*}{ Number of family } & 2 & 78 & 60.9 \\
\hline & 3 & 43 & 33.6 \\
\hline & $>3$ & 7 & 5.5 \\
\hline \multirow{3}{*}{$\begin{array}{l}\text { Family monthly } \\
\text { income }\end{array}$} & $1000-1500$ & 27 & 21.1 \\
\hline & $1500-2500$ & 42 & 32.8 \\
\hline & $>2500$ & 59 & 46.1 \\
\hline \multirow{2}{*}{ Living area } & Urban & 106 & 82.8 \\
\hline & Rural & 22 & 17.2 \\
\hline
\end{tabular}

Table 2: Maternal related characteristics of pregnant women attending Ante-natal care at Hospitals, Eastern Ethiopia, 2018.

\begin{tabular}{|c|c|c|c|}
\hline Variables & Options & Frequency & Percentage \\
\hline \multirow{4}{*}{$\begin{array}{c}\text { Age at first marriage in } \\
\text { Years }\end{array}$} & $16-20$ & 65 & 50.8 \\
\hline & $21-25$ & 33 & 25.8 \\
\hline & $26-30$ & 26 & 20.3 \\
\hline & $>=31$ & 4 & 3.1 \\
\hline \multirow{4}{*}{ Age } & $18-22$ & 65 & 50.8 \\
\hline & $23-27$ & 41 & 32 \\
\hline & $28-32$ & 22 & 16.4 \\
\hline & $>=33$ & 1 & 0.8 \\
\hline \multirow{4}{*}{ Number of pregnancy } & 1 & 66 & 51.6 \\
\hline & 2 & 42 & 32.8 \\
\hline & 3 & 18 & 14.1 \\
\hline & 4 & 2 & 1.6 \\
\hline \multirow{3}{*}{ Years of child spacing } & $<3 y$ & 51 & 39.8 \\
\hline & $3-4 y$ & 11 & 8.6 \\
\hline & $\begin{array}{c}\text { No have child } \\
\text { before }\end{array}$ & 66 & 51.6 \\
\hline \multirow{3}{*}{ Stage of pregnancy } & $1^{\text {st }}$ trimester & 50 & 39.1 \\
\hline & $2^{\text {nd }}$ trimester & 50 & 39.1 \\
\hline & $3^{\text {rd }}$ trimester & 28 & 21.9 \\
\hline \multirow{2}{*}{$\begin{array}{c}\text { Do you suffering from } \\
\text { health problem }\end{array}$} & Yes & 25 & 19.5 \\
\hline & $\mathrm{No}$ & 103 & 80.5 \\
\hline \multirow{3}{*}{$\begin{array}{l}\text { Number visit to the } \\
\text { health institution }\end{array}$} & $1^{\text {st }}$ time & 60 & 46.9 \\
\hline & $2^{\text {nd }}$ time & 43 & 33.6 \\
\hline & $3^{\text {rd }}$ time & 25 & 19.5 \\
\hline
\end{tabular}


defined the main cause of anaemia as iron deficiency. While only small proportion, $18(14.1 \%)$ of respondents identified some common symptoms of IDA namely general body weakness, dizziness or fainting, poor appetite and shortness of breathing as main sign and symptom of anaemia. On knowledge related to prevention of anaemia. Majority 75 (58.6\%) of respondents knew how anaemia can be prevented. About one third, 40 (31.3\%) of mother knew that anaemia can be prevented by healthy and balanced nutrition (Table 3).

Generally 61\% (61\% (95\% CI: $52.6 \%$ to $69.5 \%$ ) of pregnant women had a good knowledge on prevention methods of IDA. While 39\% of pregnant women had low knowledge score towards prevention of IDA. (Those who score above the mean after coding all correct options as 1 and the other as 0 ) (Figure 1).

\section{ATTITUDE OF PREGNANT MOTHERS ON IDA}

Regarding mothers attitude towards IDA, majority 52 (40.6\%)

Table 3: Knowledge of mothers on prevention of iron deficiency anaemia among pregnant women attending ANC at public hospitals of Harar town, Eastern Ethiopia, 2018.

\begin{tabular}{|c|c|c|c|}
\hline \multicolumn{2}{|c|}{ Variables } & \multirow{2}{*}{$\begin{array}{c}\text { Frequency } \\
113 \\
\end{array}$} & \multirow{2}{*}{$\begin{array}{c}\text { Percentage } \\
88.3\end{array}$} \\
\hline Fyer heard of IDA & Yes & & \\
\hline Lver hedru or HDA & No & 15 & 11.7 \\
\hline \multirow{4}{*}{ Causes of anemia } & Poor nutrition & 33 & 25.8 \\
\hline & Iron deficiency & 40 & 31.3 \\
\hline & Low hemoglobin & 7 & 5.5 \\
\hline & I don't know & 48 & 37.5 \\
\hline \multirow{7}{*}{$\begin{array}{l}\text { Sign and symptom of } \\
\text { anemia }\end{array}$} & $\begin{array}{c}\text { shortness of } \\
\text { breathing }\end{array}$ & 14 & 10.9 \\
\hline & Exceptional fatigue & 12 & 9.4 \\
\hline & $\begin{array}{l}\text { General body } \\
\text { weakness }\end{array}$ & 18 & 14.1 \\
\hline & Poor appetite & 15 & 11.7 \\
\hline & Dizziness or fainting & 18 & 14.1 \\
\hline & All can be observed & 3 & 2.3 \\
\hline & I don't know & 48 & 37.5 \\
\hline \multirow{5}{*}{ Causes of IDA } & Poor nutrition & 45 & 35.2 \\
\hline & $\begin{array}{c}\text { Bleeding during } \\
\text { pregnancy }\end{array}$ & 26 & 20.3 \\
\hline & Multiple pregnancy & 3 & 2.3 \\
\hline & All listed above & 6 & 4.7 \\
\hline & I don't know & 48 & 37.5 \\
\hline \multirow{2}{*}{$\begin{array}{c}\text { Awareness on } \\
\text { Prevention of IDA }\end{array}$} & Yes & 75 & 58.6 \\
\hline & No & 53 & 41.4 \\
\hline \multirow{5}{*}{ Ways to Prevent IDA } & By good nutrition & 40 & 31.3 \\
\hline & $\begin{array}{c}\text { Using Iron } \\
\text { supplement }\end{array}$ & 25 & 19.5 \\
\hline & $\begin{array}{l}\text { Drinking or Eating } \\
\text { fruits } \\
\end{array}$ & 7 & 5.5 \\
\hline & All listed above & 3 & 2.3 \\
\hline & I don't know & 53 & 41.4 \\
\hline \multirow{2}{*}{$\begin{array}{l}\text { drinking tea, coffee } \\
\text { and milk can cause } \\
\text { anemia }\end{array}$} & Yes & 39 & 30.5 \\
\hline & No & 89 & 69.5 \\
\hline \multirow{2}{*}{$\begin{array}{l}\text { Spacing child can } \\
\text { prevent anemia }\end{array}$} & Yes & 78 & 60.9 \\
\hline & No & 50 & 39.1 \\
\hline
\end{tabular}

and $53(41.4 \%)$ were strongly agree and agree to the statements regarding regular visit have benefit both for the mother and fetus health during pregnancy respectively. Significantly higher proportion of women, about 45 (35.2\%) and 35 (27.3\%) agreed and strongly agreed that related to drinking of tea, coffee and milk may predispose an individual to IDA respectively.

Related to feeding regular meal to prevent anaemia and iron supplement, almost half $64(50 \%)$ agreed and recommend the use of an extra iron tablet (iron supplementation) for pregnant in addition to regular diet to prevent IDA. About 46 (35.9\%) and $15(11.7 \%)$ were agreed and strongly agreed, that family planning have great role in prevention of anaemia. Almost half of pregnant women agreed that child spacing is important to prevent IDA (Table 4).

As shown in Figure 2, more than half, 52.3\% (95\% CI: 43.7\% to $61.0 \%)$ had favourable attitude towards prevention of IDA. While 67.75 of pregnant women attending ANC had unfavourable attitude towards IDA.

\section{IRON DEFICIENCY ANEMIA PREVENTION PRACTICES}

Regarding IDA prevention practice of pregnant mothers, majority 68 (53.1\%) reported that they did not drink tea, coffee and milk with their meal. While 87 (68\%) reported that they did not use iron tablet (Iron supplementation) regularly and 76 (59.4\%) reported that they

\section{Knowledge level of pregnat women attending ANC}

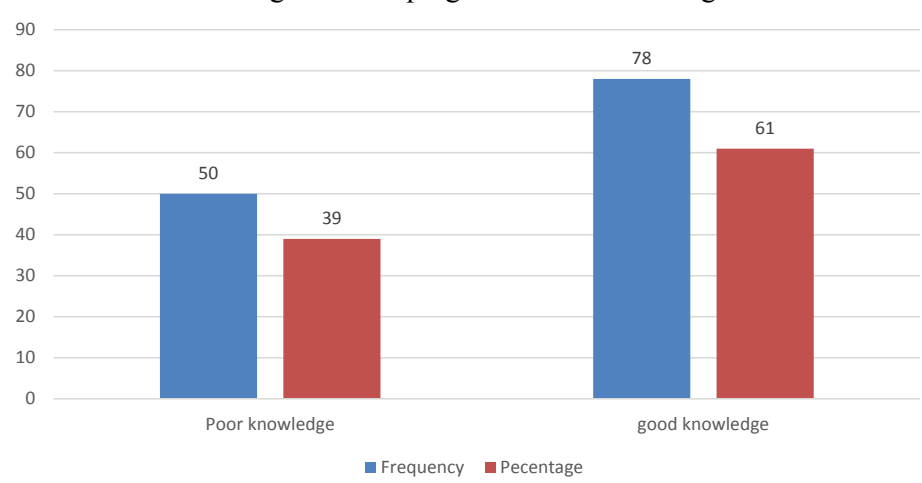

Figure 1: The overall knowledge score of pregnant mothers on IDA in Ethiopia, 2018.

\section{Attitude level of pregnant mother attending ANC}

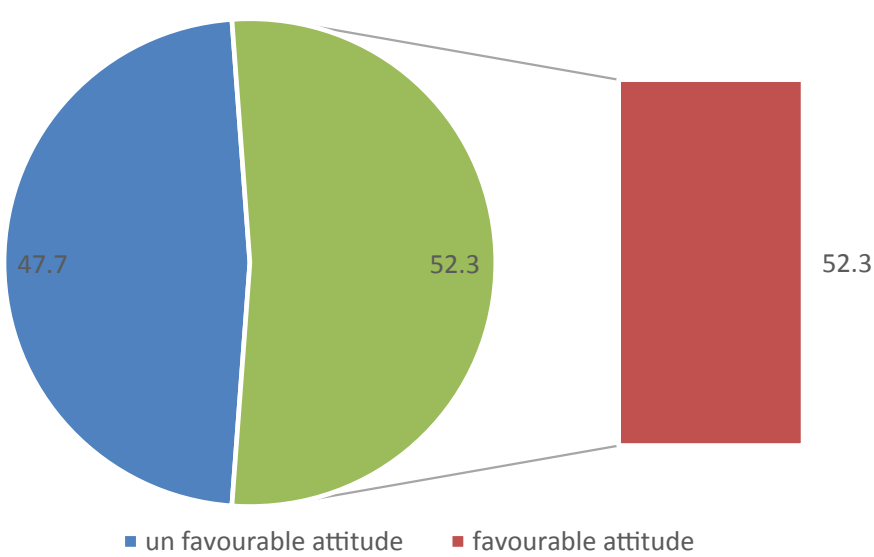

Figure 2: Attitude level of pregnant women attending ANC on the preventions of Iron deficiency anemia in Ethiopia, 2018. 
Table 4: Attitude of pregnant mothers on attitude towards iron deficiency anaemia among pregnant women attending ANC at public hospitals of Harar town, Eastern Ethiopia, 2018.

\begin{tabular}{|c|c|c|c|}
\hline & Variables & Frequency & Percentage \\
\hline \multirow{5}{*}{$\begin{array}{l}\text { Regular ANC visit is } \\
\text { good to prevent IDA. }\end{array}$} & Strongly disagree & 5 & 3.9 \\
\hline & Disagree & 1 & .8 \\
\hline & Neutral & 17 & 13.3 \\
\hline & Agree & 53 & 41.4 \\
\hline & Strongly agree & 52 & 40.6 \\
\hline \multirow{4}{*}{$\begin{array}{l}\text { Iron supplement can } \\
\text { affect mother and fetus } \\
\text { health? }\end{array}$} & Strongly disagree & 1 & .8 \\
\hline & Agree & 45 & 35.2 \\
\hline & Neutral & 47 & 36.7 \\
\hline & Strongly agree & 35 & 27.3 \\
\hline \multirow{4}{*}{$\begin{array}{l}\text { Drinking coffee, tea } \\
\text { or milk can affect iron } \\
\text { absorption }\end{array}$} & Disagree & 10 & 7.8 \\
\hline & Agree & 37 & 28.9 \\
\hline & Neutral & 70 & 54.7 \\
\hline & Strongly agree & 11 & 8.6 \\
\hline \multirow{5}{*}{$\begin{array}{l}\text { Iron supplements can } \\
\text { prevent IDA }\end{array}$} & Strongly disagree & 3 & 2.3 \\
\hline & Disagree & 2 & 1.6 \\
\hline & Agree & 50 & 39.1 \\
\hline & Neutral & 52 & 40.6 \\
\hline & Strongly agree & 21 & 16.4 \\
\hline \multirow{5}{*}{$\begin{array}{l}\text { Regular meals or } \\
\text { feeding can prevent } \\
\text { anemia }\end{array}$} & Strongly disagree & 1 & .8 \\
\hline & Disagree & 2 & 1.6 \\
\hline & Agree & 64 & 50.0 \\
\hline & Neutral & 48 & 37.5 \\
\hline & Strongly agree & 13 & 10.2 \\
\hline \multirow{5}{*}{$\begin{array}{l}\text { Pregnant women should } \\
\text { consume Iron tablets in } \\
\text { spite of healthy diet }\end{array}$} & Strongly disagree & 4 & 3.1 \\
\hline & Disagree & 10 & 7.8 \\
\hline & Agree & 46 & 35.9 \\
\hline & Neutral & 53 & 41.4 \\
\hline & Strongly agree & 15 & 11.7 \\
\hline \multirow{5}{*}{$\begin{array}{l}\text { Promotion of family } \\
\text { planning methods for } \\
\text { spacing with prevent } \\
\text { anemia }\end{array}$} & Strongly disagree & 1 & .8 \\
\hline & Disagree & 2 & 1.6 \\
\hline & Agree & 60 & 46.9 \\
\hline & Neutral & 54 & 42.2 \\
\hline & Strongly agree & 11 & 8.6 \\
\hline \multirow{5}{*}{$\begin{array}{l}\text { Spacing child can } \\
\text { prevent anemia }\end{array}$} & Strongly disagree & 8 & 6.3 \\
\hline & Disagree & 0 & 0 \\
\hline & Agree & 54 & 42.2 \\
\hline & Neutral & 51 & 39.8 \\
\hline & Strongly agree & 15 & 11.7 \\
\hline \multirow{5}{*}{$\begin{array}{l}\text { Any pregnant women } \\
\text { can be affected by } \\
\text { anemia }\end{array}$} & Strongly disagree & 4 & 3.1 \\
\hline & Disagree & 9 & 7.0 \\
\hline & Agree & 53 & 41.4 \\
\hline & Neutral & 49 & 38.3 \\
\hline & Strongly agree & 13 & 10.2 \\
\hline
\end{tabular}

practice regular feeding three times per day. On other hand 62 (48.4\%) had habit of Eating red meat. Regarding the haematological profile of pregnant mothers, one third 41 (32\%) were found to be anaemic $(\mathrm{Hgb}<11 \mathrm{mg} / \mathrm{dl})$. While majority of pregnant women, 58.6\% (95\% CI: $50.1 \%$ to $67.1 \%$ ) had poor adherence to prevention practice of IDA. On the other hand, $41.4 \%$ of ANC attending pregnant women had good adherence to prevention practice of IDA (Table 5).

\begin{tabular}{|c|c|c|c|}
\hline Variables & Options & Frequency & Percentage \\
\hline \multirow{2}{*}{$\begin{array}{l}\text { Have you drink tea, coffee and } \\
\text { milk with meal? }\end{array}$} & Yes & 60 & 46.9 \\
\hline & No & 68 & 53.1 \\
\hline \multirow{2}{*}{$\begin{array}{c}\text { Have you used regular iron } \\
\text { Tablets? }\end{array}$} & Yes & 41 & 32.0 \\
\hline & No & 87 & 68.0 \\
\hline \multirow{2}{*}{$\begin{array}{l}\text { Have you use three regular } \\
\text { meals? }\end{array}$} & Yes & 76 & 59.4 \\
\hline & No & 52 & 40.6 \\
\hline \multirow{2}{*}{$\begin{array}{c}\text { Have you taken Folic acid } \\
\text { supplements in current } \\
\text { pregnancy? }\end{array}$} & Yes & 76 & 59.4 \\
\hline & No & 52 & 40.6 \\
\hline \multirow{2}{*}{$\begin{array}{l}\text { Do you have the habit of Eating } \\
\text { red meat, liver, chicken, fish }\end{array}$} & Yes & 62 & 48.4 \\
\hline & No & 66 & 51.6 \\
\hline \multirow{2}{*}{$\begin{array}{l}\text { Do you include fiber rich food } \\
\text { frequently? }\end{array}$} & Yes & 72 & 56.3 \\
\hline & No & 56 & 43.8 \\
\hline \multirow{2}{*}{$\begin{array}{c}\text { Do you include green leafy } \\
\text { vegetable in your diet every day? }\end{array}$} & Yes & 75 & 58.6 \\
\hline & No & 53 & 41.4 \\
\hline \multirow{2}{*}{ IDA practice level } & $\begin{array}{l}\text { Good IDA } \\
\text { practice }\end{array}$ & 75 & 58.6 \\
\hline & $\begin{array}{l}\text { Good IDA } \\
\text { practice }\end{array}$ & 53 & 41.4 \\
\hline
\end{tabular}

Table 5: Practice of pregnant mothers on prevention of iron deficiency anaemia among pregnant women attending ante-natal care at public hospitals of Harar town, Eastern Ethiopia, 2018.

The mean knowledge, attitude and practice score of women was 5.4 $(\mathrm{SD}=3.7), 32.8(\mathrm{SD}=5.4)$ and $3.4(\mathrm{SD}=0.71)$ respectively. Higher knowledge score is positively correlated with attitude score $(\mathrm{r}=0.75$, $\mathrm{p}<0.001)$. Similarly higher attitude is associated with increased practice towards prevention of IDA $(r=0.55 ; \mathrm{P}<0.001)$. Rather there is relatively moderate correlation between mother knowledge and practice of $\operatorname{IDA}(\mathrm{r}=0.45 ; \mathrm{P}<0.001)$. The mean practice score of rural mother was significantly lower than urban $(\mathrm{F}=12.478 ; \mathrm{P}=0.01)$ (Table 6).

\section{DISCUSSION}

This study assessed the knowledge, attitude and practice towards prevention method of IDA. In this study, awareness related to cause of anaemia most had knew poor nutrition, bleeding during pregnancy and multiple pregnancy as cause for IDA. Similar study done in Palestine, inadequate nutrition including not having a balanced diet containing protein-rich foods, not consuming iron supplements and the presence of malaria were reported as main cause of anaemia. But study in other part showed that only $3 \%$ of mothers elicited iron deficiency as cause of anaemia [24]. While similar study showed that malaria is main cause of anaemia. In other study showed more than half, (68.1\%) recognized lack of iron in food as the cause for anaemia $[8,14,25]$.

But our study also showed poor awareness level (31.3\%) on the role

\begin{tabular}{|c|c|c|c|c|c|c|c|}
\hline \multicolumn{8}{|c|}{ ANOVA Table } \\
\hline & & & $\begin{array}{l}\text { Sum of } \\
\text { Squares }\end{array}$ & $\mathrm{df}$ & $\begin{array}{c}\text { Mean } \\
\text { Square }\end{array}$ & $\mathrm{F}$ & Sig. \\
\hline \multirow{2}{*}{$\begin{array}{l}\text { Practice } \\
\text { score }^{*} \\
\text { Residence }\end{array}$} & $\begin{array}{l}\text { Between } \\
\text { Groups }\end{array}$ & (Combined) & 5.767 & 1 & 5.767 & 12.478 & .001 \\
\hline & $\begin{array}{l}\text { Within } \\
\text { Groups }\end{array}$ & & 58.233 & 126 & .462 & & \\
\hline
\end{tabular}

Table 6: The IDA prevention practice of Pregnant mother against Residence (urban versus rural) in Ethiopia, 2018. 
of Iron in causing anaemia. Thus as more than half of anaemia is attributed to Iron deficiency, mothers had poor knowledge on major cause of anaemia [10]. This difference can be due to the difference in socioeconomic level of participants and the quality of health care (ANC) given in the two country. This emphasizes the need for better integration and implementation of counselling schedules with each visit.

Awareness level towards IDA is above average (88.1\%) which is similar in study done Sierra Leone shows $99 \%$ had heard about anaemia [25]. While $58.6 \%$ of mothers were found to be aware on prevention of IDA. Almost half of mothers are not aware that the role of fibres, coffee and tea after meal in decreasing the fractional absorption iron with almost $70 \%$ responded negatively. There is a need for focused and simple counselling by health professionals (specifically ANC care givers) on the causes and managements of IDA.

Despite this scientific fact, almost $46 \%$ of pregnant reported to have habit of drinking coffee or tea immediately after meal. Study done in Ethiopia showed that consuming tea/coffee immediately after food (AOR: 3.58) and not eating meat (AOR: 2.07) were associated with significant risk of anaemia [26]. This low awareness level in conjunction with low practice of three day meal, use of iron rich foods and low compliance to iron tablets (32\%), it high likely that the study participants are at higher risks of anaemia. But in other side of the fact shows that almost $50 \%$ of IDA can be prevented by iron supplementation [15].

Also regarding awareness on sign and symptoms of IDA, body weakness (fatigue) and shortness of breath was mostly but still majority did not mention the listed manifestations in advance. This will greatly impede the health care seeking behaviours of mothers by early detection of minor symptoms. This in turn greatly advances the stage of anaemia and its adverse pregnant and neonatal outcomes [9].

In this study most of participants agree and strongly agree on use of family planning and consuming of iron tablets in order to prevent IDA. It is a strongly recommended that pregnant women should take iron and folic acid supplementation for a period of six months. In addition it is well known that birth spacing practice by mother prevents anaemia $[2,10]$. Similarly almost greater than half of mother reported that they strongly recommend iron supplementation, family planning for the prevention of IDA which is similar finding with the responses of pregnant mothers in this study [24,27].

Study done on 400 admitted pregnant women (5) only $45.3 \%$ of participants had used iron supplements during pregnancy, which is higher in our study. Despite the universal recommendation to use iron tablet during recommendation, in our study only $32 \%$ has reported that they regularly took iron folic acid tablet for prevention or treatment of anaemia. While relatively higher adherence to Iron tablet use of $62 \%$ was reported with $79.4 \%$ of participants have had regular three times meal per day. Still there is a great geographical variation in the practice of IDA prevention strategies.

In study conducted in Ethiopia regarding knowledge and prevention practices, $57.3 \%$ and $50 \%$ of pregnant women had good knowledge ad good attitude respectively [28]. Generally 61\% (95\% CI: 52.6\% to $69.5 \%$ ) of pregnant women had a good knowledge on prevention methods of IDA. More than half, 52.3\% (95\% CI: 43.7\% to 61.0\%) had favourable attitude towards prevention of IDA. While majority of pregnant women $58.6 \%$ (95\% CI: $50.1 \%$ to $67.1 \%$ ) had poor adherence to prevention practice of IDA. Even if the results are comparable with other studies, the level of knowledge, attitude and good practices on IDA are not satisfactory $[14,23,28]$. In that still it still need great effort by hospitals and the government at large to improve their awareness and practice. As the role of husbands is tremendous in improving the health care plan of women, husbands need to be part of the ANC service.

Thus there are tremendous factors that aggravate and made pregnant at risks of anaemia in addition to the physiological vulnerability. These behavioural and other factors need to be addressed in the country specific targets for making the Sustainable Development goals in reality in the near future and decreasing anaemia by half in the coming 2025 [1].

\section{CONCLUSION}

Knowledge, attitude and practice of pregnant women on preventions of IDA are not satisfactory. Thus poor practice towards prevention of IDA is the main contributing factor for high burden of anaemia. Low adherence of mothers towards dietary and behavioural related practices of pregnant mothers was not satisfactory.

\section{RECOMMENDATION}

Based on the results of the study, there should be focused, simple, easy to understand and customer friendly counselling service at ANC facilities. It should specifically focus on symptoms of anaemia, causes, what makes pregnant at risk, how to prevent IDA among pregnant. These programs should involve males/husbands for sustained impacts. The need for adherence counselling and follow up on Iron supplement should be focused by health professionals.

\section{REFERENCES}

1. World Health organization. WHA Global Nutrition Targets 2025: Anaemia Policy Brief. 2014.

2. Noronha JA, Khasawneh EA, Raman S, Seshan V. Anemia in pregnancy and challenges. J South Asian Federation Obs Gynaecol. 2012;4(1):64-70

3. Lim SS, Vos T, Flaxman AD, Danaei G, Shibuya K, Adair RH, et al. A comparative risk assessment of burden of disease and injury attributable to 67 risk factors and risk factor clusters in 21 regions, 1990-2010: A systematic analysis for the Global Burden of Disease Study 2010. Lancet. 2012;380:2224-2260.

4. https://www.who.int/nutrition/publications/decade-of-actioncommitment-policybrief/en/

5. Endang, Luis, Michael A, Komal B. Global Nutrition Report Action and accountablity in Global Nutrition Report. 2014;20-40.

6. Bhutta Z, Das J, Rizvi A, Gaffey MF, Walker N, Horton S, et al. Evidence-based interventions for improvement of maternal and child nutrition: What can be done and at what cost? Matern Child Nutr 2. 2013;1-15.

7. https://www.tcd.ie/tidi/assets/doc/Development\%20Research\%20 Week\%202013/Bob\%20Black_Maternal_Child_Nutrition.pdf

8. Tay K, Agboli E, Walana W. Malaria and anemia in pregnant and non-pregnant women of child-bearing age at the University Hospital, Kumasi, Ghana. J Med Microbiol. 2013;3(3):193-200.

9. Chang S, Zeng L, Brouwer ID, Kok FJ, Yan H. Effect of Iron deficiency 
anemia in pregnancy on child mental development in rural China. Pediatr. 2013;131(3):e755-e763.

10. World Health organization. Haemoglobin concentrations for the diagnosis of anaemia and assessment of severity VMNIS Vitamin and Mineral Nutrition Information System. 2011;Pp:2-5.

11. Khusun H, Yip R, Schultink W, Dillon DHS. World Health Organization Hemoglobin Cut-Off Points for the Detection of Anemia Are Valid for an Indonesian Population. J Nutr. 1999;129(9):1669-1674.

12. Jack F, Agostino D, Sununtnasuk. Nutrition technical brief: A simple method for making a rapid, initial assessment of the consumption and distribution of iron-folic acid supplements among pregnant women in developing Countries. 2014.

13. World Health Organization. Global anaemia prevalence and number of individuals affected. Vitamin and Mineral Nutrition Information System (VMNIS). 2008.

14. Guedenon KM, Atakouma YD, Macamanzi E, Dossou FC, Gbadoe AD. Knowledge, attitude and practice of the mothers with anemia of children under five years old in the peadiatric department at Sylvanus Olympio teaching hospital in Lome. Tunis Med. 2016;94(1):46-53.

15. World Health organization. The Global prevalence of anemia in 2011. 2015.

16. Ethiopia Mini Demographic and Health Survey. Central Statistical Agency Addis Ababa, Ethiopia. 2014;Pp:53-58.

17. Kefiyalew F, Zemene E, Asres Y, Gedefaw L. Anemia among pregnant women in Southeast Ethiopia: Prevalence, severity and associated risk factors. BMC Res Notes. 2014;3:771.

18. Lealem G, Asrat A, Yaregal A, Andualem M. Anemia and Associated Factors Among Pregnant Women Attending Antenatal Care Clinic in Wolayita Sodo Town, Southern Ethiopia. Ethiop J Health Sci. 2015;25(2):155-162.
19. Gebremedhin S, Enquselassie F, Umeta M. Prevalence and correlates of maternal anemia in rural Sidama. Southern Ethiopia Afr J Reprod Health. 2014;18(1):44-53.

20. Jufar AH, Zewde T. Prevalence of anemia among pregnant women attending antenatal care at tikur anbessa specialized hospital, Addis Ababa Ethiopia. J Hematol Thromb Dis. 2014;2(1):1-6.

21. Lebso M, Anato A, Loha E. Prevalence of anemia and associated factors among pregnant women in Southern Ethiopia: A community based cross-sectional study. PloS. 2017;12(12):e0188783.

22. Harari Regioal statistics: A population projection from census. Harar. Pp: 5-17.

23. Maj SS, Laxmipriya P. Study to Assess the Knowledge and Practices Regarding Prevention of Anaemia among Antenatal Women Attending a Tertiary Level Hospital in Pune. Int J Sci Res. 2017.

24. Amani WM. Iron Deficiency Anemia among Pregnant Women in Nablus District; Prevalence, Knowledge, Attitude and Practices. 2007.

25. Fredanna AD, Cormack M, Judy CD. Assessment of Anemia Knowledge, Attitudes and behaviors among pregnant women in Sierra Leone. ERIC. 2012;44(2):9-16.

26. Weldekidan F, Kote M, Girma M, Boti N, Gultie T. Determinants of Anemia among Pregnant women attending antenatal clinic in public health facilities at Durame Town: Unmatched Case Control Study. Anemia. 2018;p:8.

27. Hussain T, Shu LY. Awareness of iron deficiency anemia among women of reproductive age in Hubei province, China. Asian J Med Sci. 2010;1(1):12-13.

28. Keneni B, Jayanthigopal D, Bayissa DD. Assessment of knowledge and practice towards prevention of anemia among pregnant women attending antenatal care at government hospitals in West Shoa Zone. Ethiop J Health Med Nurs. 2018;50:31-40. 